\title{
Menilik Urgensi Penerapan Pembiayaan Akad Salam pada Bidang Pertanian di Lembaga Keuangan Syariah di Indonesia
}

\author{
Widiana $^{1}$, Arna Asna Annisa² \\ ${ }^{1}$ Universitas Padjajaran \\ ${ }^{2}$ IAIN Salatiga \\ 1'widiana1108@gmail.com; 2arnaannisa@gmail.com
}

\begin{abstract}
The financing of salam covenant is one of sharia banking products that can be used in the field of agriculture, but this has not been used in sharia financial institutions in Indonesia. Covenant of salam has strategic potential for agricultural development. This paper aims to illustrate the potential of using salam covenant in financing which is conducted by customer and how the challenges of implementation of salam covenant in Islamic financial institutions. This is a descriptive qualitative research. In Indonesia, both Islamic banking and Baitul Maal Wattamwil have not applied this contract, related to some risks from salam financing. Sharia financial institutions needs a strategy in order to feel the benefits of providing salam. This article describes the practice of financing system of profitable covenant agreement for the sharia financial institution and the community. The research finding showed that by optimizing salam covenant financing, it can give positive impact to farmers that is in capital aspect to develop agricultural product.
\end{abstract}

Keywords: salam covenant financing; agriculture; syariah financial institution

\begin{abstract}
Abstrak
Pembiayaan akad salam merupakan salah satu produk perbankan syariah yang dapat digunakan dalam bidang pertanian, namun hal ini belum digunakan dalam Lembaga Keuangan Syariah (LKS) di Indonesia. Akad salam memiliki potensi strategis terhadap pengembangan bidang pertanian. Penelitian ini bertujuan untuk menggambarkan potensi penggunaan akad salam dalam pembiayaan yang dilakukan oleh nasabah dan bagaimana tantangan atas penerapan pembiayaan akad salam di lembaga keuangan syariah. Tulisan ini berpijak pada penelitian kualitatif dengan metode deskriptif analisis dari berbagai literatur. Di Indonesia, baik perbankan syariah maupun Baitul Maal Wattamwil (BMT) belum menerapkan akad ini, terkait beberapa risiko dari pembiayaan salam. Lembaga keuangan syariah membutuhkan strategi agar dapat merasakan keuntungan dari penyediaan produk salam. Dalam tulisan ini dijelaskan praktik sistem pembiayaan akad salam yang menguntungkan bagi lembaga keuangan syariah dan masyarakat. Hasil yang diperoleh menunjukkan bahwa dengan optimalisasi pembiayaan akad salam dapat memberikan dampak positif terhadap para petani yaitu pada aspek permodalan untuk mengembangkan produk pertanian.
\end{abstract}

Kata Kunci: pembiayaan akad salam, pertanian, lembaga keuangan syariah 


\section{PENDAHULUAN}

Berdasarkan data dari FAO (2016), Indonesia menempati peringkat ketiga dunia sebagai negara produsen beras dengan total produksi beras sekitar 79,36 juta ton/tahun. Indonesia berada di bawah China sebagai negara penghasil beras terbesar didunia dengan jumlah produksi sebanyak 206,5 juta ton/tahun dan India yang menempati posisi kedua dengan jumlah produksi sekitar 153,8 juta ton/tahun. Data tersebut semakin menegaskan posisi Indonesia sebagai negara agraris.

Menjadi tolok ukur yang signifikan ketika jumlah produksi pangan menurun berarti perlu adanya reorientasi kebijakan antar sektor, agar sektor pertanian Indonesia terus meningkat dan dapat memenuhi kebutuhan pangan masyarakat tanpa harus impor beras. Hasil sensus pertanian (ST) tahun 2013 mempresentasikan sebuah gambaran bahwa sebanyak 14.250 .000 rumah tangga petani $(55,3 \%)$ di Indonesia merupakan petani gurem (Badan Pusat Statistik, 2013). Oleh karena itu, petani gurem memegang peranan penting dalam penyediaan kebutuhan hasil tani Indonesia.

Namun, petani gurem (petani yang memiliki atau menyewa lahan pertanian kurang dari 0,5 ha) belum dapat diandalkan secara penuh dalam memenuhi kebutuhan karena risiko yang mereka hadapi. Risiko ini mempengaruhi perilaku petani untuk memutuskan apakah akan meningkatkan produktivitasnya atau tidak. Dari data BPS per Desember 2013, jumlah rumah tangga petani gurem pada 2013 mengalami penurunan sebesar $25,07 \%$ sejak tahun 2003.

Dari data tersebut, jelas menggambarkan banyaknya petani yang beralih profesi atau malah menyewakan lahannya. Hal ini disebabkan penjualan atau penyewaan lahan mereka untuk dialihfungsikan atau beralih profesinya para petani gurem tersebut. Secara umum kondisi petani gurem dipengaruhi oleh rentenir modal dan tengkulak. Rentenir seringkali memberikan pinjaman dengan bunga modal yang cukup besar. Disisi lain, tengkulak menjadi momok bagi petani karena tidak jarang mereka merugikan petani dengan mematok harga yang sangat rendah. (www.bbc.com/indonesia/ indonesia-41078646)

Petani gurem menghadapi risiko dari berbagai sumber. Hal ini membuat petani gurem seperti terikat dan tidak mampu mengembangkan hasil pertaniannya karena terbatasnya modal, bunga yang tinggi untuk membayar pinjaman, risiko gagal bayar, dan perilaku tengkulak. Padahal, petani merupakan ujung tombak untuk meningkatkan produksi pangan. Unsur utama yang menciptakan ketidakadilan ini adalah "bunga" yang menjadi dasar dari rentenir untuk memberikan biaya modal atau pinjaman lain kepada petani. Berbagai penyakit sosio-ekonomi dapat teratasi jika menggantikannya melalui mekanisme modal dan investasi terkait risiko tanpa bunga (Ayub, 2007). Hukum asal muamalah di dalam Islam ialah diperbolehkan kecuali ada ketentuan syariat yang melarang hal tersebut. Larangan ini disebabkan dapat membantu berbuat maksiat/ bertindak yang dilarang Allah, adanya unsur penipuan, adanya unsur menzalimi pihak yang bertransaksi dan lainnya (Nurhayati, dalam Wiroso, 2011).

Pembiayaan berbasis syariah menjadi penting. Hal tersebut bertujuan untuk mewujudkan sikap tolong-menolong, kerelaan, dan terhindar dari tindakan menzalimi dan dizalimi serta yang paling utama adalah terhindar dari sistem riba. Oleh karena itu, Indonesia perlu menerapkan pembiayaan syariah dalam rangka peningkatan pembiayaan 
di sektor pertanian.

Produk pembiayaan dengan akad salam menjadi alternatif solusi. Akad salam atau disebut juga akad beli tangguh adalah akad pembiayaan suatu barang dengan cara pemesanan dan pembayaran harga yang dilakukan terlebih dahulu dengan syarat tertentu yang disepakati. Hal ini sangat sesuai dengan kondisi petani di Indonesia yang rata-rata hanya memiliki modal kecil, dan baru akan memiliki uang jika masa panen sudah tiba. Tentunya apabila akad salam ini dapat diakses oleh petani, hal ini akan sangat membantu mereka lepas dari jeratan rentenir.

Penelitian yang dilakukan oleh Roziq, Hisamudin, Wahyuni \& Purnawati (2014) yang berjudul "Model Pembiayaan Salam pada Petani Singkong dan Usaha Kecil Berbahan Singkong di Kabupaten Jember", menyatakan bahwa tidak ada pembiayaan salam yang diperoleh petani singkong baik dari industri/usaha tape, keripik singkong maupun tepung singkong, di lembaga keuangan syariah seperti Bank Syariah Mandiri, Bank Muamalat, BPR Syariah ASRI Madani Nusantara maupun BMT Sidogiri.

Qusthoniah (2016) menulis tentang "Analisis Kritis Akad Salam di Perbankan Syariah". Hasil dari telaahnya menyebutkan bahwasanya akad salam ialah akad penjualan barang dengan kriteria tertentu dan pembayaran di muka. Maka menjadi suatu keharusan apabila barang yang dipesan adalah barang yang dapat ditentukan melalui penyebutan kriteria. Penyebutan kriteria ini bertujuan untuk menentukan barang yang diinginkan oleh kedua belah pihak, seakan-akan barang yang dimaksud ada di hadapan mereka berdua. Dengan demikian, ketika jatuh tempo, diharapkan tidak terjadi percekcokan kedua belah pihak seputar barang yang dimaksud. Sehingga akad salam bisa menjadi solusi agar usaha yang dilakukan oleh petani bisa berjalan tanpa tekanan dan minim masalah.

Berdasar latar belakang diatas, maka tulisan ini akan mengkaji bagaimana urgensi penerapan akad salam pada bidang pertanian di lembaga keuangan syariah serta diharapkan dapat menjadi khazanah pemikiran dan solusi alternatif bagi penyelesaian masalah-masalah di sektor pertanian yaitu pada aspek pengembangan dan perluasan produk-produk pertanian.

\section{METODOLOGI}

Tulisan ini bertujuan untuk memperoleh gambaran tentang penerapan akad salam dalam bidang pertanian di lembaga keuangan syariah. Metode yang digunakan adalah deskriptif kualitatif yang memaparkan model penerapan akad salam dan urgensinya dalam bidang pertanian di Indonesia. Metode penelitian kualitatif dapat diartikan sebagai metode penelitian yang berlandaskan pada filsafat postpositivisime, digunakan untuk meneliti pada kondisi objek yang alamiah, dimana peneliti sebagai instrument kunci, teknik pengumpulan data dilakukan secara triangulasi (gabungan), analisis data bersifat induktif/kualitatif, dan hasil penelitian kualitatif lebih menekankan makna dari pada generalisasi (Sugiyono, 2015).

\section{PEMBAHASAN}

Pembangunan pertanian merupakan salah satu sektor utama dalam pembangunan nasional. Hal ini berkaitan dengan peran sektor pertanian dalam penyediaan lapangan 
pekerjaan, penyumbang PDB, sebagai penghasil pangan, papan dan energi. Di samping itu, sektor pertanianlah yang mampu bertahan serta lebih fleksibel terhadap gejolak krisis ekonomi seperti yang terjadi pada krisis ekonomi tahun 1997/1998.

Secara umum, peran sektor pertanian bagi pembangunan ekonomi menurut Todaro \& Smith (2006) adalah sebagai berikut: (a). Pertanian sebagai penyerap tenaga kerja, (b). Menyumbangkan kontribusi terhadap pendapatan masyarakat, (c). Memberikan kontribusi dalam penyediaan pangan, (d). Pertanian sebagai penyedia bahan baku industri, (e). Memberikan kontribusi dalam bentuk pembentukan modal (capital), dan (f). Pertanian sebagai sumber devisa. Tantangan yang terjadi di Indonesia saat ini terkait produksi beras nasional ialah kebutuhan pangan yang terus meningkat, alih fungsi lahan pertanian ke non-pertanian, baik untuk papan maupun industri tidak dapat dihindari, upah buruh tani yang rendah, dan kesulitan dalam pengadaan sarana prasarana produksi. Selain hal tersebut, peran sektor pertanian juga sangat besar dalam pembangunan perekonomian jika dilihat dari kacamata agribisnis. Kegiatan budaya pertanian akan berdampak terhadap bergeraknya kegiatan input produksi dalam penyediaan benih/bibit, pupuk, fungsida, pakan, vaksin dan obat-obatan.

Pertanian memiliki peran signifikan dalam kehidupan nasional. Data dari Badan Pusat Statistik tahun 2016 menyebutkan bahwa produksi padi pada tahun 2015 sebesar 75,4 juta ton Gabah Kering Giling (GKG), dan meningkat menjadi 79,36 juta ton GKG ditahun 2016 dan 81,57 juta ton GKG di tahun 2017. Namun, pencapaian tersebut belum dapat mengimbangi kebutuhan masyarakat Indonesia terhadap kebutuhan pangan. Jika dikaitkan dengan jumlah penduduk Indonesia tahun 2017 yang berjumlah 262 juta jiwa maka rata-rata konsumsi perkapita/pertahun sebesar $114,6 \mathrm{~kg} / \mathrm{kapita} / \mathrm{tahun}$. Ini membuktikan bahwa tingkat konsumsi beras itu tinggi seiring pertambahan jumlah penduduk.

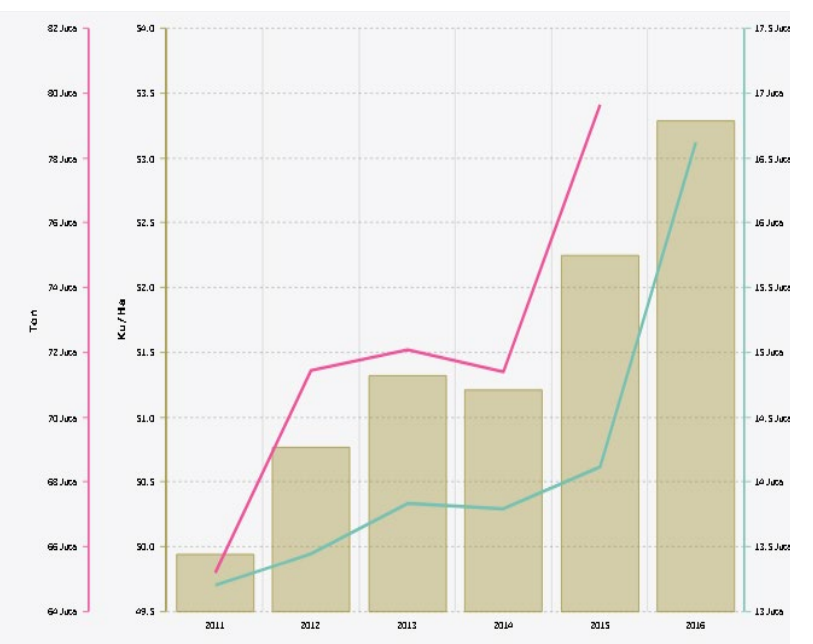

Gambar 1. Produksi, Luas Lahan Panen, dan Produktivitas Padi 2011-2016

Di sisi lain, dalam Laporan Bidang Rembuk Kedaulatan Pangan dan Mengelola Keamanan Pangan tahun 2017 menyebutkan bahwasanya kemiskinan di pedesaan sedikit 
menurun dari 14,7\% pada Maret 2014 menjadi 13,93\% pada Maret 2017; atau sebesar $0,24 \%$. Penurunan kemiskinan ini terlalu kecil dibanding pertumbuhan ekonomi yang rata-rata 4,97\% per tahun dalam 3 tahun terakhir serta inflasi yang berada di bawah $4 \%$. Kualitas pertumbuhan dan trickle down effect tidak terjadi. Hal yang diperkuat dengan indeks kedalaman dan indeks keparahan kemiskinan yang justru meningkat dari 2,26 menjadi 2,49 dan dari 0,57 menjadi 0,67. Nilai Tukar Petani (NTP) sebagai salah satu indikator kesejahteraan petani menurun dari 101,98 (Januari-September 2014) menjadi 100,71 (Januari-September 2017). NTP Tanaman Pangan memiliki nilai terendah dan semakin menurun dari 98,59 menjadi 97,21 di periode yang sama. Dengan demikian, dapat disimpulkan bahwa penurunan kesejahteraan sangat terasa di lapangan.

Masih dalam laporan yang sama, empat komoditas mengalami kenaikan yang tinggi selama 3 tahun terakhir ini ditengah inflasi yang cukup rendah. Empat komoditas tersebut yaitu: daging sapi $(16,5 \%)$, beras medium $(18,9 \%)$, gula pasir $(19,7 \%)$, dan bawang merah $(47,8 \%)$ yang juga meningkatkan biaya operasional usaha tani, dan tentunya hal ini sangat memberatkan petani kita. Upaya untuk menurunkan harga ditingkat konsumen pun juga langsung berdampak buruk terhadap petani. Indonesia perlu segera melakukan perbaikan demi menjaga kebutuhan pangan di masa sekarang dan yang akan datang, yaitu dengan cara meningkatkan kesejahteraan petani, memperbaiki infrastuktur pertanian, dan keterjangkauan harga sarana produksi seperti pupuk, benih, dan obat-obatan, serta kebijakan peruntukan lahan.

Di sisi lain kepincangan pembangunan pertanian adalah tidak adanya lembaga pembiayaan khusus untuk pertanian sehingga berimplikasi pada sulitnya para petani untuk mendapatkan modal untuk pengembangan usaha. Selama ini pembiayaan pertanian diserahkan saja pada bank umum dengan program kredit yang disubsidi pemerintah. Namun petani sangat sulit untuk mengaksesnya karena pihak bank memberikan persyaratan yang sangat ketat, kehati-hatian bank sangat tinggi terhadap pembiayaan pertanian karena pada dasarnya bisnis pada sektor pertanian sangat berisiko tinggi, hal inilah yang menjadi alasan bagi pihak perbankan berhati-hati dalam memberikan kredit dan memang pada dasarnya kehati-hatian (prudent) adalah ciri dari lembaga perbankan. Selain itu, riba dalam bentuk bunga juga menghantui setiap kredit yang dilakukan di lembaga keuangan konvensional.

Menurut Beik (dalam Ridlwan, 2016) penyaluran kredit kepada sektor pertanian sampai dengan akhir Tahun 2010 mencapai Rp 91 triliun atau 5,15\% dari total kredit perbankan. Di antara kredit tersebut, sebesar Rp1,76 triliun atau 1,9\% merupakan pembiayaan yang disalurkan perbankan syariah. Hal ini menunjukan bahwa skala pembiayaan pertanian masih sangat kecil. Bahkan angka tersebut jauh di bawah pembiayaan untuk sektor lain seperti perindustrian dan perdagangan, restoran dan hotel, serta pengangkutan. Hal ini terjadi karena pihak perbankan belum tertarik untuk meningkatkan proporsi pembiayaan sektor ini.

Berbagai jenis program kredit telah diluncurkan pemerintah untuk sektor pertanian, seperti Kredit Bimas, Inmas, Kredit Usaha Tani (KUT), Kredit Ketahanan Pangan (KKP) dan Kredit Usaha Rakyat (KUR), namun program tersebut masih belum cukup optimal dalam memberdayakan petani yang ditunjukkan dengan masih lemahnya kemampuan petani dalam permodalan. Selain dari program kredit dan bank komersial, pembiayaan pertanian di pedesaan juga banyak ditopang lembaga kredit nonformal, 
seperti para pembunga uang (money lenders) yang berprofesi sebagai pedagang output, pedagang input, pemilik penggilingan padi ataupun para petani kaya.

Salah satu ciri paling menonjol dari kredit pertanian baik formal maupun nonformal adalah skema kredit tersebut selalu berbasis bunga (interest), padahal sektor pertanian yang sarat dengan risiko memiliki peluang kegagalan yang tinggi, baik dalam produksi maupun jatuhnya harga. Jika petani gagal dalam usaha taninya, disamping tidak akan mampu mengembalikan pinjaman, mereka juga dapat terjerat hutang yang makin lama makin membengkak. Model kredit ini juga membebankan segala risiko usaha hanya kepada peminjam (petani), sementara pemilik dana selalu mendapat untung sebesar tingkat bunga yang telah ditetapkan. Untuk menjamin rasa keadilan, perlu dicari pembiayaan alternatif yang sesuai dengan sifat sektor pertanian. Salah satu bentuk pembiayaan yang mulai berkembang adalah pembiayaan syariah di lembaga keuangan syariah.

\section{Pembiayaan Akad Salam di Lembaga Keuangan Syariah}

Secara teori, ada tiga hal yang menjadi penciri dari pembiayaan berbasis syariah, yaitu (1). Bebas bunga, (2). Berprinsip bagi hasil dan risiko, dan (3). Perhitungan bagi hasil tidak dilakukan di muka, yang pada dasarnya sangat sesuai dengan karakteristik kegiatan sektor pertanian dan juga terkait dengan agama yang dipeluk oleh sebagian besar petani yaitu Islam. Berbeda dengan kredit konvensional yang memperhitungkan suku bunga di depan, ekonomi syariah menghitung hasil setelah periode transaksi berakhir. Hal ini berarti dalam pembiayaan syariah pembagian hasil dilakukan setelah ada keuntungan riil, bukan berdasar hasil perhitungan spekulatif. Sistem bagi hasil ini dipandang lebih sesuai dengan iklim bisnis yang memang mempunyai potensi untung dan rugi.

Secara umum produk perbankan syariah dapat dibagi menjadi tiga bagian yaitu produk penyaluran dana, penghimpunan dana, dan produk yang berkaitan dengan jasa yang diberikan kepada nasabahnya. Pada produk penghimpunan dana, skema yang digunakan berupa wadi'ah dan mudharabah. Untuk menyalurkan dana pembiayaan syariah, perbankan syariah menggunakan skema prinsip jual beli (ba'i), prinsip sewa (ijaroh) dan prinsip bagi hasil (syirkah). Sedangkan pada produk jasa menggunakan skema jual beli valuta asing (sharf) dan sewa (ijaroh).

Hampir seluruh perbankan konvensional memberlakukan sistem bunga (interest) dalam menjalankan fungsinya sebagai penghimpun dan menyalurkan dana kepada nasabahnya. Sistem bunga pada dasarnya sangat berbahaya bagi pembiayaan pada sektor riil termasuk bidang pertanian karena berisiko tinggi (high risk). Berkaitan dengan hal tersebut pembiayaan syariah sangat berpotensi dalam pembiayaan pada sektor pertanian karena produk-produk perbankan syariah bebas dari bunga.

Dalam lembaga keuangan syariah, pembiayaan syariah bisa diberikan dalam akad jual beli (bai') yaitu istishna, murabahah, dan salam. Dalam tulisan Mujiatun (2013) tentang "Jual Beli Dalam Perspektif Islam: Salam dan Istisna" dijelaskan bahwa akad istishna yang merupakan akad dengan perjanjian jual beli dengan cara memesan barang yang bukan komoditi atau barang pertanian tapi barang yang dibuat dengan mesin dan keahlian khusus, seperti perlengkapan kitchen set, kursi dan meja makan atau konstruksi bangunan, dimana barang tersebut dipesan dan dibuat sesuai dengan ketentuan yang diminta oleh pembeli dengan spesifikasi yang khusus. Sedangkan Annisa (2013) dalam 
penelitian yang berjudul "Penetapan Harga Jual Produk Murabahah Studi Kasus di BMT Rama Salatiga" menjelaskan bahwa murabahah lebih banyak digunakan untuk barang-barang konsumsi dan barang modal non pertanian. Sedangkan jual beli dengan akad salam adalah produk lembaga keuangan syariah yang paling banyak dipakai untuk pembiayaan kepada petani.

Salam adalah akad jual beli barang pesanan (muslam fih) dengan pengiriman barang di kemudian hari oleh penjual (muslam illaihi) dan pelunasannya dilakukan oleh pembeli pada saat akad disepakati sesuai dengan syarat-syarat tertentu (PAPSI, 2013).

Sumber hukum akad salam adalah sebagai berikut:

"Hai orang-orang yang beriman, apabila kamu bermu'amalah tidak secara tunai untuk waktu yang ditentukan, hendaknya kamu menuliskannya dengan benar..." (QS. AlBaqarah: 282)

"Barang siapa melakukan salam, hendaknya ia melakukannya dengan takaran yang jelas dan timbangan yang jelas pula, untuk jangka waktu yang diketahui."(HR. Bukhari Muslim)

Ketentuan syariah dari akad salam menurut Wiroso (2011), yaitu:

a. Ketentuan tentang pembayaran

1. Alat bayar harus diketahui jumlah dan bentuknya, baik berupa uang, barang, atau manfaat.

2. Pembayaran harus dilakukan saat kontrak disepakati.

3. Pembayaran tidak boleh dalam bentuk pembebasan hutang.

b. Ketentuan tentang barang

1. Harus jelas ciri-cirinya dan dapat diakui sebagai hutang.

2. Harus dapat dijelaskan spesifikasinya.

3. Penyerahnnya dilakukan kemudian.

4. Waktu dan tempat penyerahan barang harus ditetapkan berdasarkan kesepakatan.

5. Pembeli tidak boleh menjual barang sebelum menerimanya.

6. Tidak boleh menukar barang, kecuali dengan barang sejenis sesuai kesepakatan.

c. Ketentuan tentang salam paralel

Dibolehkan melakukan salam paralel dengan syarat akad kedua terpisah dari dan tidak berkaitan dengan akad pertama.

d. Penyerahan barang sebelum atau pada waktunya

1. Penjual harus menyerahkan barang tepat pada waktunya dengan kualitas dan jumlah yang telah disepakati.

2. Jika penjual menyerahkan barang dengan kualitas yang lebih tinggi, penjual tidak boleh meminta tambahan harga.

3. Jika penjual menyerahkan barang dengan kualitas yang lebih rendah, dan pembeli rela menerimanya, maka tidak boleh menuntut pengurangan harga (diskon).

4. Penjual dapat menyerahkan barang lebih cepat dari waktu yang disepakati dengan syarat kualitas dan jumlah barang sesuai dengan kesepakatan dan ia tidak boleh menuntut tambahan harga.

5. Jika semua atau sebagian barang tidak tersedia pada waktu penyerahan atau kualitasnya lebih rendah dan pembeli tidak rela menerimanya, maka ia memiliki 
dua pilihan :

- Membatalkan kontrak dan meminta kembali uangnya

- Menunggu sampai barang tersedia

- Pembatalan kontrak

Pada dasarnya pembatalan salam boleh dilakukan, selama tidak merugikan kedua belah pihak.

Pembiayaan akad salam pada umumnya digunakan untuk transaksi pertanian. Dengan adanya akad ini dapat memberikan peluang bagi masyarakat khususnya petani untuk memperoleh modal dalam bercocok tanam sehingga permasalahan mengenai keterbatasan dana dalam bertani dapat teratasi. Petani juga akan belajar tanggung jawab karena jika terjadi sesuatu terhadap hasil tani maka itu tidak hanya akan merugikan dirinya sendiri akan tetapi juga bagi pemberi pembiayaan. Setidaknya ada tanggungjawab moral yang memacu kesungguhan dari petani dalam menjalankan usahanya. Pelatihan dalam bertani yang baik dan cara mengatur keuangan juga perlu dilakukan oleh pemberi pembiayaan agar dana yang digulirkan dapat digunakan secara efektif dan efisien.

Pemerintah seharusnya memperhatikan lembaga keuangan syariah yang fokus menerapkan akad salam. Karena ini bisa membantu pemerintah dalam mengakomodir pembiayaan akad salam yang jarang tersentuh oleh LKS saat ini. LKS ini tentu saja harus memiliki pemahaman yang baik terhadap akad salam. LKS harus bisa mempertimbangkan mengenai prospek pertanian yang layak untuk diberikan dana pembiayaan menggunakan akad salam. Konsep kehati-hatian perlu ditingkatkan dalam pemberian pembiayaan akan tetapi ini tidak bermaksud untuk mempersulit para petani. Nantinya LKS bisa saja membuat suatu standar kelayakan mengenai poin pokok yang harus dipenuhi petani agar bisa memperoleh pembiayaan salam. Selain itu LKS juga harus memiliki sistem yang terstruktur agar tujuan dari penerapan pembiayaan salam dapat tercapai.

Penelitian dari Muhammad, Stiabudi \& Ashar (2017) memberikan alternatif atas pelaksanaan akad salam dalam pembiayaan untuk bidang pertanian di perbankan syariah. Penelitian tersebut mengusung konsep untuk mengoptimalkan akad salam di perbankan syariah dalam mengatasi permasalahan permodalan di sektor pertanian, yakni dengan bekerja sama pada asuransi pertanian untuk meng-cover biaya permodalan yang tidak bisa dibayarkan oleh petani ketika terjadi gagal panen. Hal itu tentunya menjadi angin segar bagi penerapan akad salam di lembaga keuangan syariah yang selama ini urung dilakukan karena resiko yang harus mereka hadapi. Asuransi syariah atau takaful akan memberikan pertanggungan atas resiko yang muncul dalam setiap proses pembiayaan salam untuk bidang pertanian. Dengan begitu, LKS akan terhindar dari resiko kerugian yang muncul dari pembiayaan akad salam yang diberikan kepada petani.

Petani atau nasabah yang datang kepada lembaga keuangan syariah untuk melakukan pembiayaan dengan akad salam akan melakukan transaksi sekaligus kesepakatan yang didalamnya sudah termasuk asuransi yang menjadi satu dengan akad yang ditandatangani. Maka dari itu, selain harga pokok dan keuntungan dari LKS, yang perlu diperhitungkan adalah nilai asuransi dari barang yang diperjualbelikan.

Selain dengan menggandeng asuransi pertanian, bentuk penerapan konsep salam yang efektif bagi LKS adalah menjalin hubungan simbiosis antara produk hulu dengan produk hilir. Memetakan rantai produksi dan menjadi penjembatan di dalamnya. Mulai dari produsen bibit, produsen pupuk, produsen alat-alat pertanian, sampai pada konsumen 
langsung ataupun juga konsumen yang siap menjadikan hasil pertanian sebagai produk olahan.

LKS juga seharusnya memiliki jaringan yang digunakan untuk pemasaran hasil tani setelah panen tiba sehingga dapat membantu petani dalam mendistribusikan hasil panen. Sehingga perputaran modal pembiayaan akan cepat pergerakannya. Secara teori memang dibutuhkan kesungguhan dalam menerapkan akad salam karena akad salam sangat berisiko bagi LKS karena jika terjadi gagal panen ini juga akan berdampak pada LKS. Akan tetapi disisi lain pembiayaan akad salam masih belum banyak diterapkan pada lembaga keuangan syariah. Ini juga merupakan peluang bagi LKS yang ingin fokus dalam penerapan pembiayaan salam. Ditambah lagi dengan melihat kondisi alam dari tanah Indonesia yang sangat subur maka pengembangan pembiayaan salam sangat berpeluang besar untuk sukses.

Bagi perekonomian Indonesia tentu saja pembiayaan salam akan berdampak positif, karena Indonesia merupakan lumbung padi bagi pemenuhan keperluan dalam negeri. Sebagai lumbung padi, tidak perlu mengimpor beras dari negara lain untuk pemenuhan beras. Selain itu sektor pertanian merupakan lapangan pekerjaan bagi masyarakat yang sangat luas, terutama bagi masyarakat pedesaan. Maka sudah selayaknya jika akad salam di-support sepenuhnya oleh pemerintah untuk bisa menjadi solusi bagi petani.

Jika sektor pertanian dioptimalkan, maka angka urbanisasi dapat menurun dan lapangan pekerjaan akan merata sampai ke desa-desa. Bagi pemuda yang berada di desa tidak perlu malu dengan profesinya sebagai petani, karena dengan pembiayaan salam, bertani akan menggunakan sistem yang terstruktur. Tentu saja ini memerlukan perhatian yang besar dari pemerintah mengingat bahwasannya beras adalah makanan pokok orang Indonesia dan Indonesia adalah market terbesar di dunia sehingga ini merupakan kesempatan emas jika disikapi dengan kebijakan-kebijakan yang pro rakyat dan pro syariah.

\section{Penerapan Akad Salam di Indonesia}

Sebagian besar perbankan syariah menerapkan akad jual beli murabahah, akad bagi hasil mudharabah atau musyarakah. Hal ini dikarenakan akad tersebut memungkinkan diterapkan pada perbankan syariah. Akad salam masih jarang digunakan, karena perbankan tidak ingin mengambil resiko yang akan terjadi. Bank syariah memiliki kekhawatiran jika bank telah mengeluarkan pembiayaan salam, di kemudian hari ternyata para petaninya mengalami gagal panen atau tidak sesuai dengan harapan. Ini yang dihindari perbankan syariah. Jikalau bank syariah melakukan akad salam, maka yang dilakukan adalah akad salam paralel, yaitu bank terlebih dahulu mempunyai nasabah yang telah bersedia membeli hasil tani yang diperoleh dari petani.

Salam adalah transaksi jual beli dimana barang yang diperjualbelikan belum ada. Oleh karena itu barang diserahkan secara tangguh sedangkan pembayaran dilakukan tunai. Bank bertindak sebagai pembeli sedangkan nasabah sebagai penjual produk. Dalam praktik perbankan, ketika barang telah diserahkan kepada bank, maka bank akan menjualnya kepada rekanan nasabah atau kepada nasabah itu sendiri secara tunai atau secara angsuran. Harga yang ditetapkan bank adalah harga beli bank dari nasabah ditambah keuntungan. Dalam hal ini bank menjualnya secara cicilan, kedua pihak harus menyetujui harga jual dan jangka waktu serta pembayaran. Adapun ketentuan umum salam sebagai berikut; 
1). Pembelian hasil produk pertanian harus diketahui spesifikasinya secara jelas, seperti jenis, macam, ukuran, mutu dan jumlahnya. Misalnya jual beli $100 \mathrm{~kg}$ mangga harum manis kualitas "A” dengan harga Rp 15000/kg akan diserahkan pada panen bulan mendatang.

2). Apabila hasil produksi yang diterima cacat atau tidak sesuai dengan akad, maka nasabah (produsen) harus bertanggung jawab dengan cara antara lain: mengembalikan dana yang diterimanya atau mengganti sesuai dengan pesanan.

3). Mengingat bank tidak menjadikan barang yang dibeli atau dipesannya sebagai persediaan (inventory), maka dimungkinkan bagi bank untuk melakukan akad salam kepada pihak ketiga (pembeli kedua) seperti Bulog, pedagang pasar induk, eksportir atau industri pengolah, mekanisme seperti ini disebut dengan salam paralel.

Pembiayaan dengan akad salam sebenarnya diakui eksistensinya di perbankan syariah. Hal ini ditunjukkan dalam data statistik perbankan syariah yang dipublikasikan oleh Bank Indonesia mulai tahun 2003 hingga sekarang, pembiayaan dengan akad salam selalu ditampakkan dalam setiap laporan tahunannya. Tetapi data menunjukkan bahwa akad salam sudah tidak lagi diterapkan di perbankan syariah. Selain itu, Bank Indonesia selaku otoritas industri perbankan juga telah menetapkan standarisasi bagi akad salam dalam PBI (Peraturan Bank Indonesia) tentang Akad Penghimpunan dan Penyaluran Dana bagi Bank yang melaksanakan kegiatan usaha berdasarkan prinsip syariah, yang tercantum dalam pasal 11 dan pasal 12. Disamping itu juga adanya aturan baku tentang penerapan akuntansi akad salam yang tercantum dalam PSAK No.103 tentang Akuntansi Salam (Tanjung \& Devi, 2013).

Sejak tahun 2002, pembiayaan dengan akad salam di perbankan syariah tidak ada sama sekali, kecuali pada bulan ke-3 tahun 2002 sebesar 0,02\% (392 juta). Sementara itu BPRS juga menerapkan akad salam dengan proporsi pembiayaan yang semakin menurun. Menurut data BPRS pada tahun 2005, pembiayaan dengan akad salam sebesar Rp. 90 juta dan angka ini menurun drastis di awal tahun 2009 hingga sebesar Rp. 38 juta. Berdasarkan data statistik perbankan syariah dari tahun 2007 hingga bulan Juli tahun 2009, komposisi pembiayaan untuk sektor pertanian tidak lebih dari 5\%. Proporsi bank syariah ke sektor pertanian pun mengalami perubahan yang tidak signifikan dari tahun ke tahun. Tercatat pembiayaan bank syariah untuk sektor pertanian pada tahun 2007 sebesar $3,49 \%$ dari total keseluruhan pembiayaan bank syariah, lalu menurun hingga ke angka 3,04\% dipertengahan tahun 2009. Meskipun demikian hal ini harus tetap diapresiasi karena lembaga keuangan mikro ini masih mau menyalurkan pembiayaan dengan akad salam (Tanjung \& Devi, 2013).

Sebagian besar petani masih belum pernah mendapatkan pembiayaan dengan menggunakan akad salam dari LKS padahal petani sangat antusias dalam menanggapi pembiayaan salam. BPR (Badan Perkreditan Rakyat) Syariah memiliki alokasi dana untuk membiayai akad salam akan tetapi hal ini tidak di aplikasikan, karena dalam praktiknya BPR Syariah menggunakan pembiayaan akad al-murabahah untuk hasil pertanian dan pembiayaan akad ijarah untuk sewa lahan pertanian. BPR Syariah belum menerapkan pembiayaan salam dikarenakan akad salam rawan terjadi kecurangan yang dilakukan, jika petani tidak menyerahkan hasil panen sesuai akad.

Skema transaksi salam tetap potensial dikembangkan di Indonesia seiring 
dengan meningkatnya perhatian pemerintah untuk mengembangkan sektor pertanian. Secara khusus, jika pemerintah terlibat dalam upaya mengembangkan kemampuan akses pendanaan petani, penggunaan skema salam relatif lebih tepat dan lebih menguntungkan dibanding skema lainnya.

Keuntungan menggunakan skema salam antara lain:

\section{a. Bagi petani}

Skema salam dengan pembayaran di muka akan sangat membantu petani dalam membiayai kebutuhan petani dalam memproduksi barang pertanian. Dengan demikian, petani memiliki kesempatan dan dorongan yang lebih besar untuk meningkatkan kapasitas produksinya agar dapat menghasilkan produk pertanian yang lebih banyak sehingga disamping untuk diserahkan kepada pembeli sebanyak yang sudah ditetukan, juga dapat digunakan untuk diri sendiri atau untuk dijual pihak lain.

b. Bagi pemerintah

Penggunaan skema salam dengan ciri pembayaran di muka akan mempercepat pencapaian target-target pemerintah dalam mendorong peningkatan cadangan pengadaan produksi pertanian. Skema ini dipandang dapat mengantisipasi keengganan petani menjual kepada pedagang besar. Keuntungan lainnya bagi pemerintah adalah dengan tercapainya cadangan pengadaan produk pertanian dengan dana yang terjangkau, maka akan mempercepat peran pemerintah dalam ekspor produk pertanian ke luar negeri yang belakangan ini mengalami kenaikan harga.

c. Bagi pengusaha

Penggunaan skema salam bagi pengusaha berpotensi meningkatkan efisiensi dan nilai penjualan pengusaha produk pertanian. Pengusaha yang dalam hal ini berperan sebagai penjual produk pertanian baik untuk konsumsi lokal maupun ekspor, akan dapat memiliki produk pertanian dari petani dengan harga yang relatif lebih rendah dibanding harga pasar mengingat pembayaran yang dilakukan di muka. Adanya harga pembelian yang relatif lebih murah tersebut akan memberikan keuntungan bagi pengusaha untuk memperoleh marjin yang menarik. Keuntungan lain bagi pengusaha adalah adanya kepastian memperoleh barang yang diinginkan, sehingga tidak perlu khawatir atas persaingan mendapatkan barang pada saat panen dengan pengusaha lain.

d. Bagi bank syariah

Skema salam pada dasarnya sangat menguntungkan bagi bank syariah mengingat pembeli sudah menyerahkan uangnya terlebih dahulu di muka. Dengan demikian, resiko kegagalan membayar utang tidak ada sama sekali. Walau transaksi ini menimbulkan risiko baru, yaitu kegagalan menyerahkan barang, dengan pengalaman dan jaringan petani yang dimiliki bank resiko ini mestinya tidak sulit untuk diatasi oleh bank syariah.

Pembiayaan akad salam akan menguntungkan BPRS Syariah jika kualitas dan kuantitas barang sesuai dengan kesepakatan awal. Pada kenyataannya bisa saja kualitas dan kuantitas barang yang diberikan berbeda. Langkah yang mungkin dapat dilakukan BPRS Syariah adalah dengan menggunakan salam paralel untuk meminimalisir risiko. Baitul Mal Wattamwil (BMT) dalam aplikasinya sering memberikan pembiayaan di sektor pertanian akan tetapi akad yang digunakan adalah akad rahn dan ijarah bukan akad salam. Hal ini dikarenakan jika adanya penurunan harga terhadap barang yang dibeli dari petani maka akan menyebabkan penurunan keuntungan yang akan diperoleh BMT (Roziq et al, 2014). 
Penerapan pembiayaan salam memerlukan konsep yang matang agar dapat dipahami baik secara teori maupun praktik langsung di lapangan. Pemerintah dapat membentuk lembaga keuangan syariah (LKS) baik berbentuk perbankan maupun lembaga formal lainnya yang dapat mengaplikasikan konsep pembiayaan salam. LKS ini dilengkapi dengan sistem dan permodalan dari pemerintah yang berfokus pada pembiayaan salam. Sebelum pendirian LKS, pemerintah harus melakukan penelitian terhadap daerah yang nantinya akan dijadikan tempat berdirinya LKS ini. Setidaknya ada 2 kriteria yang dipenuhi desa/daerah tersebut yaitu:

1. Desa/daerah memiliki tanah yang subur dan iklim yang cocok untuk dibuka lahan pertanian (SDA).

2. Desa/daerah memiliki petani yang dapat mempertanggungjawabkan dana pembiyaan salam yang akan digulirkan (SDM).

Setelah kriteria desa/daerah terpenuhi maka selanjutnya didirikanlah LKS yang bersifat independen dalam pengelolaanya dan bertanggungjawab langsung kepada pemerintah. Selanjutnya LKS yang telah berdiri melakukan seleksi terhadap petani yang layak dalam penerimaan pembiayaan salam. Setelah dilakukan seleksi maka selanjutnya LKS memberikan pembekalan khusus kepada petani yang akan menerima dana pembiayaan salam.

Pembekalan ini berisi materi seputar pertanian, peluang pertanian di Indonesia dan dunia, serta pengelolaan keuangan. Hal ini bertujuan untuk menambah wawasan agar pemikiran petani yang ada di daerah tersebut terbuka akan perkembangan yang terjadi secara nasional maupun internasional. Setelah itu LKS dan petani melakukan akad salam, yaitu LKS bertindak sebagai pembeli (muslam) dan petani sebagai penjual (muslam ilaih) yang ditandai dengan adanya pemesanan dari LKS terkait kualitas dan kuantitas beras dan LKS memberikan dana pembiayaan salam kepada petani yang akan digunakan dalam bertani. LKS juga mengadakan pendampingan kepada petani, agar petani dapat berkonsultasi dengan mudah jika terjadi kendala-kendala dalam menjalankan pertanian.

Jika masa panen telah tiba maka petani menyerahkan hasil tani berupa beras kepada LKS. Sampai disini tugas LKS adalah menjual kembali beras tersebut yang tujuan utama pangsa pasarnya yaitu kepada warga masyarakat daerah setempat. Hal ini dilakukan agar konsep dari rakyat untuk rakyat dapat diterapkan, sehingga akan terbentuk lumbung padi secara mandiri di tiap daerah yang terdapat LKS di dalamnya. Jika kebutuhan akan beras di daerah tersebut sudah terpenuhi maka LKS dapat mengekspor beras ke luar desa/daerah. Selanjutnya pokok dana dan pendapatan uang hasil penjualan beras digunakan kembali sebagai dana pembiayaan salam kepada petani.

Berikut ini adalah alur penerapan pembiayaan salam pada LKS dan masyarakat:

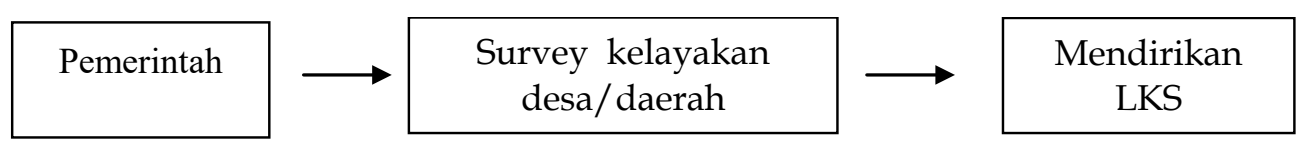

Gambar 2. Skema penerapan pembiayaan akad salam 


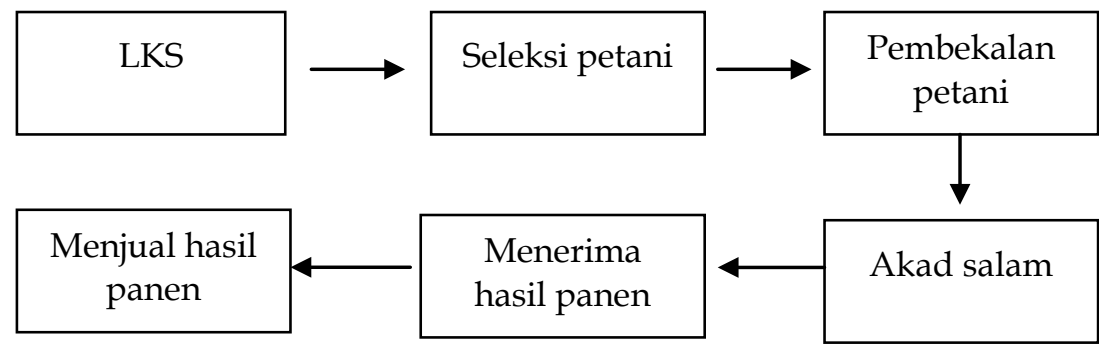

Gambar 3. Skema penerapan pembiayaan akad salam

\section{KESIMPULAN}

Penerapan pembiayaan akad salam masih kurang dioptimalkan oleh LKS. Pembiayaan salam dapat memberikan kontribusi dan menanggulangi permasalahan pangan yang sedang dihadapi Indonesia. Seharusnya dengan sumber daya alam yang subur dan adanya rakyat sebagai sumber daya manusia yang siap menggarapnya, maka hal ini dapat dijembatani dengan adanya sistem pembiayaan akad salam yang mana akad tersebut dapat menjadi sistem yang efektif jika di terapkan dengan sungguh-sungguh.

Sangat jelas bahwa, akad salam diatur dalam fatwa Dewan Syariah Nasional (DSN) dan tercantum di dalam Pernyataan Standar Akuntansi Keuangan (PSAK) Syariah serta Pedoman Akuntansi Perbankan Syariah Indonesia (PAPSI) sehingga peraturan ini tidak boleh disia-siakan dan harus dimanfaatkan untuk kepentingan pengembangan ekonomi negara. Dengan skema pembiayaan akad salam yang telah dibuat diharapkan dapat memberikan sedikit kontribusi dalam penerapan pembiayaan salam. Pemerintah dengan kebijakannya dapat memberikan dukungan terhadap ekonomi rakyat melalui ekonomi syariah.

\section{DAFTAR PUSTAKA}

Annisa, A. A. (2013). Penetapan Harga Jual Produk Murabahah Studi Kasus di BMT Rama Salatiga. Salatiga. Muqtasid: Jurnal Ekonomi dan Perbankan Syariah, 4(2).

Anonimus. (2013). Pedoman Akuntansi Perbankan Syariah Indonesia. Bank Indonesia, Jakarta Ayub, M. (2007). Understanding Islamic Finance. Jakarta: PT. Gramedia.

BPS. (2015). Statistik Indonesia Tahun 2015. Jakarta Pusat: Badan Pusat Statistik

Muhammad, B., Stiabudi, R., \& Ashar, M. (2017). Paper Salam Plus: Inovasi Produk Akad Salam pada Perbankan Syariah untuk Meningkatkan Produktivitas Pertanian Indonesia. Syariah Economy Week. UMY Yogyakarta.

Mujiatun, S. (2013). Jual Beli dalam Perspektif Islam: Salam dan Istisna. Medan: Jurnal Riset Akuntansi dan Bisnis UMSU, 13 (2).

Qusthoniah. (2016). Analisis Kritis Akad Salam di Perbankan Syariah.Indragiri: Jurnal Syari'ah UNISI, $V(1)$.

Ridlwan, A. A. (2016). Implementation Akad Muzara'ah In Islamic Bank: Alternative To Access Capital Agricultural Sector. Iqtishoduna: Jurnal Ekonomi Islam, 7(1).

Roziq, A., Hisamuddin, N., Wahyuni, N. I., Purnawati, I. (2014). Model Pembiayaan Salam pada Petani Singkong dan Usaha Kecil Berbahan Singkong di Kabupaten Jember. Jember: Jurnal Akuntasi Universitas Jember, 12 (2).

Sugiyono. (2015). Metode Penelitian Manajemen. Bandung: Alfabeta.

Tanjung, H., \& Devi, A. (2013). Metodologi Penelitian Ekonomi Islam. Jakarta: Gramata 
Publishing.

Todaro, M. P., \& Smith, S. C. (2006). Pembangunan Ekonomi (Edisi ke Sembilan, Jilid 1). Jakarta: Erlangga.

Wiroso. (2011). Akuntansi Transaksi Syariah. Jakarta: Ikatan Akuntan Indonesia 